\title{
Phytochemical Profiling and in vitro Screening for Neuritogenic and Antioxidant Activities of Spirulina platensis
}

\author{
Ee-Ling Ngu', Chen-Lin Ko', Cheng-Yau Tan', Kah-Hui Wong' ${ }^{2}$, Siew-Moi Phang ${ }^{3,4}$, Yoon-Yen Yow ${ }^{1, *}$ \\ ${ }^{1}$ Department of Biological Sciences, School of Medical and Life Sciences, Sunway University, Bandar Sunway, \\ Selangor Darul Ehsan, MALAYSIA. \\ ${ }^{2}$ Department of Anatomy, Faculty of Medicine, Universiti Malaya, Kuala Lumpur, MALAYSIA. \\ ${ }^{3}$ Faculty of Applied Sciences, UCSI University, Cheras, Kuala Lumpur, MALAYSIA. \\ ${ }^{4}$ Institute of Ocean and Earth Sciences, University of Malaya, Kuala Lumpur, MALAYSIA.
}

\begin{abstract}
Background: In neurological diseases, neuronal loss is frequently associated with overproduction of free radicals and reduced level of endogenous neurotrophic factors. The blue-green microalga, Spirulina platensis is a well-known superfood with a high content of diverse nutrients and possesses several therapeutic properties. Here, we aimed to study the neuritogenic and antioxidant activities of Spirulina platensis UMACC 159. Materials and Methods: PC-12Adh (rat pheochromocytoma) cell was used to investigate the cytotoxicity effect of S. platensis UMACC 159 extracts (water, methanol, and ethanol) via 3-(4,5-dimethylthiazol-2-yl)-2,5-diphenyltetrazolium bromide (MTT) assay. Neuritogenic activity of the extracts towards PC-12Adh cell line was studied using neurite outgrowth assay and immunofluorescence imaging of neurofilaments. The extracts were screened for the phytochemical contents, and antioxidant activities using 2,2'-Azino-bis(3-ethylbenzothiazoline-6-sulfonic acid) (ABTS), 2,2-Diphenyl-1pircrylhydrazyl (DPPH) and reducing power. Results: Ethanol extract was found to exhibit the highest neuritogenic effect and enhanced the cytoskeleton formation in PC-12Adh cells at $6.25 \mu \mathrm{g} / \mathrm{mL}$. Ethanol extract also showed the highest total phenolic content $(49.09 \pm 1.35 \mathrm{mg} \mathrm{GAE} / \mathrm{g})$, ABTS $\left(\mathrm{EC}_{50}\right.$ of $\left.1.34 \pm 0.01 \mathrm{mg} / \mathrm{mL}\right)$ and DPPH $\left(\mathrm{EC}_{50}\right.$ of 0.45 $\pm 0.04 \mathrm{mg} / \mathrm{mL}$ ) scavenging activities $(P \leq 0.05)$, suggesting that the neuritogenic effect of ethanol extract was attributed to the phenolic compound(s) via antioxidant activity. Conclusion: Ethanol extract contains bioactive compound(s) with similar neuritogenic activity as nerve growth factor for neuronal survival, growth, and axonal regeneration. S. platensis has been proposed as a promising cognitive supplement.
\end{abstract}

Key words: Spirulina platensis, Antioxidants, Cytotoxicity, Neuronal outgrowth, Phytochemicals.

\section{INTRODUCTION}

Deaths caused by dementia increased more than doubled within 16 years, making dementias the $5^{\text {th }}$ leading cause of global deaths in 2016. ${ }^{1}$ Currently, drugs approved for Parkinson's Disease (PD) by the Food and Drug Administration (FDA), such as levodopa and rivastigmine are symptomatic therapies. These drugs come with adverse effects, for example motor fluctuations and dyskinesias for levodopa; nausea, dyspepsia, and asthenia for rivastigmine., ${ }^{2,3}$ Therefore, there is a need to discover novel compounds to counter against neurodegenerative diseases.

In various neurodegenerative diseases, the loss of neuron is a common hallmark accompanied by excess free radicals and insufficient endogenous neurotrophic factors. Reactive oxygen species (ROS) are byproduct of aerobic metabolism, and are highly reactive whereby overproduction can induce oxidation of biomolecules including
Submission Date: 08-04-2021; Revision Date: 19-05-2021; Accepted Date: 07-07-2021

DOI: 10.5530/ijper.55.3.154 Correspondence: Dr. Yoon-Yen Yow Department of Biological Sciences, School of Medical and Life Sciences, Sunway University, 47500 Bandar Sunway, Selangor Darul Ehsan, MALAYSIA.

Phone: +60 (3) 74918622 Email id: yoonyeny@sunway. edu.my

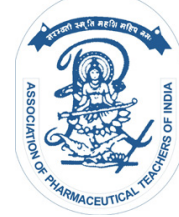

www.ijper.org 
proteins and nucleic acid, eventually result in neuronal death. ${ }^{4}$ Nerve growth factor (NGF) is a neurotrophic factor crucial for neuronal growth, survival and regeneration. ${ }^{5,6}$ NGF has potent neuroprotective property via promoting neuronal survival and stimulating neurite outgrowth. ${ }^{6}$ Neurite outgrowth or neuritogenesis is the process where neurons produce and elongate the neurites to construct neuronal communications network. ${ }^{5}$ Diminutions in the level of NGF cause major declines in brain cell performance resulting in neurodegenerative diseases. ${ }^{6}$ Although direct administration into $\mathrm{AD}$ patient's brain showed encouraging results, ${ }^{7}$ NGF failed to travel across the blood-brain barrier due to high molecular weight polypeptides. ${ }^{6}$ Hence, the unearthing of NGF-potentiating substances with low molecular weight from natural sources are believed to be the new alternative therapeutic drugs.

Different species of microalgae, namely Cylindrotheca closterium, Odontella mobiliensis, Pseudo-nitzschia pseudo delicatissima, Skeletonema marinoi, Leptocylindrus danicus, and Leptocylindrus aporus have exhibited therapeutic activities such as anti-inflammatory, anticancer, antibacterial, and anti-biofilm activities. ${ }^{8}$ Nannochloropsis sp. also had neuroprotective activity against neuroinflammation and oxidative DNA damage., ${ }^{910}$ In fact, eicosapentaenoic acid in Nannochloropsis oceanica defends against oxidative stress by upregulating the levels of antioxidant enzymes in Neuro-2A cells. ${ }^{11}$ The blue-green microalga, Spirulina platensis is a prokaryotic filamentous cyanobacterium that belongs to the genus of Arthrospira. Spirulina is commonly known as a superfood due to its high content of diverse nutrients. In 2012, Spirulina has been nominated as a safe nutritional supplement by both the World Health Organization (WHO) and FDA. ${ }^{12,13}$ S. platensis is known to possess several therapeutic properties, including immunomodulation, ${ }^{14}$ wound healing enhancement, ${ }^{15}$ antiallergic, ${ }^{16} \quad$ anticancer, ${ }^{17}$ antimicrobial, ${ }^{18,19}$ antioxidative, antidiabetic, antihypertensive, ${ }^{20}$ and anti-inflammation. ${ }^{21,22}$ Antioxidative property of S. platensis gives rise to various type of protective effects, such as UV-protection, ${ }^{21}$ renal protection, ${ }^{23}$ hepatoprotection ${ }^{22}$ and neuroprotection. ${ }^{24,25} \mathrm{~S}$. platensis protects dopaminergic neurons via anti-oxidation and anti-inflammatory mechanisms $\mathrm{s}^{24,25}$ and also promotes recovery of spinal cord injury in animal model. ${ }^{26}$

Numerous studies have reported the neuroprotective effect of Spirulina, but neuritogenic effect of $S$. platensis remains unknown. Hence, we aimed to examine antioxidant and neuritogenic activities of $S$. platensis extracts in rat pheochromocytoma cells (PC-12Adh). PC-12Adh cell line is commonly used to study the neuronal differentiation in both neurobiological and neurotoxicological studies. PC-12Adh cells have the morphology of noradrenergic adrenal chromaffin cells, but undergo neurite outgrowth like sympathetic neurons upon NGF stimulation. ${ }^{27}$

\section{MATERIALS AND METHODS}

\section{Preparation of solvent extracts}

Fresh S. platensis UMACC 159 was procured from the University of Malaya Algae Culture Collection (UMACC), Algae Research Laboratory, University Malaya. It was cultivated in Kosaric medium for approximately 7-10 days prior harvesting. The biomass was freeze-dried using vacuum concentrator (LaboGene, Brigachtal, Germany). The dried biomass was soaked in water, methanol, and ethanol separately $(1: 50 \mathrm{w} / \mathrm{v})$ at $37^{\circ} \mathrm{C}$, agitated for $48 \mathrm{~h}$, and the extracts were then centrifuged $\left(2,688 \times \mathrm{g}, 4^{\circ} \mathrm{C}, 20 \mathrm{~min}\right)$. By using a rotary evaporator (Fisher Scientific EYELA N-1200A, Tokyo), the supernatant was dried and further concentrated under vacuum (SpeedSan 40, Korea) and then kept at $-20^{\circ} \mathrm{C}$ for future use. The extraction yield $(\%)$ was determined using the equation (1):

Extraction yield $(\%)=\frac{\text { Weight of concentrated extract }(\mathrm{g})}{\text { Dry weight of powder }(\mathrm{g})} \times 100 \%$

\section{Cell culture}

PC-12Adh cell line (ATCC® CRL-1721.1TM) was cultured in Ham's F-12 (F-12 K) medium (Kaighn's modification) supplemented with horse serum (15\%), fetal bovine serum (2.5\%), and penicillin-streptomycin $(1 \%)$ (Sigma-Aldrich, MO, US) and incubated at $37 \pm$ $2{ }^{\circ} \mathrm{C}$ under $5 \% \mathrm{CO}_{2}$.

\section{In vitro cell viability measurement}

PC-12Adh cells were inoculated in 96-well plate with $5 \mathrm{x}$ $10^{3}$ cells/well. The cells were treated with $0-8 \mathrm{mg} / \mathrm{mL}$ of extracts and incubated for $24 \mathrm{~h}$. Ten microliter of $0.5 \mathrm{mg} /$ $\mathrm{mL}$ 3-(4,5-dimethylthiazol-2-yl)-2,5-diphenyltetrazolium bromide (MTT) (Merck and Co, NJ, US) was added and incubated for $4 \mathrm{~h}$. To solubilize formazan formed in viable cells, dimethyl sulfoxide (DMSO) was used. The absorbance at $570 \mathrm{~nm}$ (measuring) and $630 \mathrm{~nm}$ (reference) wavelengths was measured with the UV-Vis spectrophotometer microplate reader (Infinite 200 Pro, Tecan, Mannedorf, Switzerland). The cell viability (\%) was calculated using the equation (2):

Cell viability $(\%)=\frac{\text { Absorbance of sample-blank }}{\text { Absorbance of negative control }} \times 100 \%$ 
Half-maximal inhibition concentration $\left(\mathrm{IC}_{50}\right)$ was determined from the graph of cell viability (\%) against treatment concentration.

\section{Neuritogenic effect of Spirulina platensis extracts}

\section{Neurite outgrowth activity}

Neuritogenic activity was determined according to Pang et $a l^{28}$ with minor alterations. PC-12Adh cells were inoculated in 24-well plate with $5 \times 10^{3}$ cells/well and treated with NGF $(70 \mathrm{ng} / \mathrm{mL}$, positive control), culture medium (negative control) or extracts $(6.25-37.5 \mu \mathrm{g} / \mathrm{mL})$. The cells were incubated at $37 \pm 2{ }^{\circ} \mathrm{C}$ under $5 \% \mathrm{CO}_{2}$ for $48 \mathrm{~h}$. Five random fields (300-600 cells/well) from each well were examined using Nikon Eclipse Ti-S $(10 \times 10.5$ objective) and photographed with Digital Sight DS-Fi2 camera using NIS-Elements imaging software (Nikon, Tokyo, Japan). Number of neurite-bearing cells (cells with axon-like extension that is at least equal to diameter of the cell body) was counted and the percentage was calculated using the equation (3):

Neurite-bearing cells $(\%)=\frac{\text { Neurite-bearing cell number per well }}{\text { Total cell number per well }} \times$

\section{Neuronal cytoskeleton analysis by immunofluorescence imaging}

PC-12Adh cells were inoculated in 12-well cell culture chamber with $5 \times 10^{3}$ cells/well. The cells were treated with the NGF (70 $\mathrm{ng} / \mathrm{mL}$, positive control), culture medium (negative control) or optimal concentration of extracts $(6.25 \mu \mathrm{g} / \mathrm{mL})$ and incubated at $37 \pm 2^{\circ} \mathrm{C}$ under $5 \% \mathrm{CO}_{2}$ for $48 \mathrm{~h}$. Paraformaldehyde (4\%) was used to fix the cells for $20 \mathrm{~min}$. Cells were incubated with rabbit anti-neurofilament 200 polyclonal antibody (1:80, Sigma-Aldrich, cat. no. N4142) for $1 \mathrm{~h}$, followed by antirabbit $\operatorname{IgG}$ conjugated with fluorescein isothiocyanate (FITC) antibody (1:80, Sigma-Aldrich, cat. no. F7512) in the dark for $2 \mathrm{~h}$. The slide was mounted with Prolong ${ }^{\circledR}$ gold antifade mounting reagent with 4'-6-diamidino-2phenylindole (DAPI) (Life Technologies Corporation, California, US) to counterstain the nuclei. The stained cells were observed with DAPI and FITC filters under fluorescence illumination using inverted microscope. The neuronal cytoskeleton was photographed using the NIS-elements Imaging Software.

\section{Phytochemicals screening}

\section{Quantification of total phenolic content (TPC)}

TPC of extracts was measured according to Singleton et al. ${ }^{29}$ with minor alterations. Gallic acid (0-1000 $\mu \mathrm{g} /$ $\mathrm{mL)}$ (Sigma-Aldrich, Shanghai, China) served as the standard. The extracts or gallic acid $(5 \mu \mathrm{L})$ was mixed with Folin-Ciocalteu reagent $(25 \mu \mathrm{L})$ (EMD Millipore Corporation, Darmstadt, Germany) and double-distilled water $\left(\mathrm{ddH}_{2} \mathrm{O}\right)(350 \mu \mathrm{L})$, and incubated in dark for 4 min. Sodium carbonate $(75 \mu \mathrm{L}, 20 \%)$ and $\mathrm{ddH}_{2} \mathrm{O}(45$ $\mu \mathrm{L}$ ) were added with the mixture and incubated in dark for $60 \mathrm{~min}$. The absorbance at $750 \mathrm{~nm}$ was measured using the microplate reader. TPC was expressed as $\mathrm{mg}$ of gallic acid equivalent (GAE) per $\mathrm{g}$ of extract ( $\mathrm{mg}$ $\mathrm{GAE} / \mathrm{g})$.

\section{Quantification of total flavonoid content (TFC)}

TFC of extracts was quantified according to Pekal and Pyrzynska $^{30}$ with minor alterations. Quercetin (0-1000 $\mu \mathrm{g} / \mathrm{mL}$ ) (Sigma-Aldrich, Bangalore, India) served as the standard. The quercetin or extract $(10 \mu \mathrm{L})$ was mixed with methanolic aluminum chloride $(250 \mu \mathrm{L}, 2 \%)$ (Sigma-Aldrich, Munich, Germany), sodium acetic acid $(250 \mu \mathrm{L}, 1 \mathrm{M})$ and $\mathrm{ddH}_{2} \mathrm{O}(490 \mu \mathrm{L})$. The mixture was incubated in dark for $15 \mathrm{~min}$. The absorbance at 425 $\mathrm{nm}$ was measured using the microplate reader. TFC was expressed as $\mathrm{mg}$ of quercetin equivalent $(\mathrm{QE})$ per $\mathrm{g}$ of extract (mg QE/g).

\section{Qualitative determination of carotenoid and terpenoid}

Presence of carotenoid was identified according to Sharma et al. ${ }^{31}$ with minor alterations. Extract (0.01 g) was mixed vigorously with $1 \mathrm{~mL}$ of chloroform and filtered prior added with $85 \%$ sulphuric acid. Blue colour formation at the interfere indicates the presence of carotenoid. Meanwhile, the presence of terpenoid was identified according to Batista-Gonzalez et al. ${ }^{32}$ Extract $(0.01 \mathrm{~g})$ was mixed with acetic anhydride and sulphuric acid. Greenish blue colour formation indicates the presence of terpenoid.

\section{Antioxidant assays}

\section{2,2'-Azino-bis(3-ethylbenzothiazoline-6-sulfonic acid) (ABTS) scavenging activity}

ABTS scavenging activity acts on the electron transfer (ET) reaction, ${ }^{33}$ was measured according to Miller et al. ${ }^{34}$ and Re et al. ${ }^{35}$ with minor alterations. Trolox (0-1 mg/ $\mathrm{mL}$ ) (Sigma-Aldrich, St. Gallen, Switzerland) served as the positive control. Seven-millimolar ABTS (Roche, Baden-Wurttemberg, Germany) was activated through incubation with equal volume of potassium persulfate $(2.45 \mathrm{mM})$ in dark for $16 \mathrm{~h}$. Ethanol $(1: 10 \mathrm{v} / \mathrm{v})$ was used to dilute the activated ABTS to the absorbance of $0.7 \pm 0.02$ at $734 \mathrm{~nm}$. The trolox or extract $(0.1 \mathrm{~mL})$ was incubated with diluted ABTS $(1 \mathrm{~mL})$ in dark for 6 min. The absorbance at $734 \mathrm{~nm}$ was measured using the 
microplate reader. ABTS scavenging activity (\%) was calculated using the equation (4):

$$
\text { ABTS scavenging activity }(\%)=1-\frac{\text { Absorbance of samples at } 734 \mathrm{~nm}}{\text { Initial absorbance of ABTS at } 734 \mathrm{~nm}} \times 100 \%
$$

Half-maximum effective concentration $\left(\mathrm{EC}_{50}\right)$ was determined from the graph of ABTS scavenging activity $(\%)$ against the treatment concentration.

\section{2,2-Diphenyl-1-pircrylhydrazyl activity}

(DPPH)

scavenging

DPPH scavenging activity is based on ET reaction, with hydrogen transfer as an alternate pathway. ${ }^{33}$ The activity was determined according to Brand-Williams et al. ${ }^{36}$ with minor alterations. Ascorbic acid $(0-25 \mu \mathrm{g} / \mathrm{mL}$ ) (SigmaAldrich, Tokyo, Japan) served as the positive control. The ascorbic acid or extract $(50 \mu \mathrm{L})$ was incubated with DPPH (1 mL, $0.1 \mathrm{mM}$, Alfa Aesar) in dark for $30 \mathrm{~min}$. The absorbance at $518 \mathrm{~nm}$ was measured using the microplate reader. DPPH scavenging activity (\%) was calculated using the equation (5):

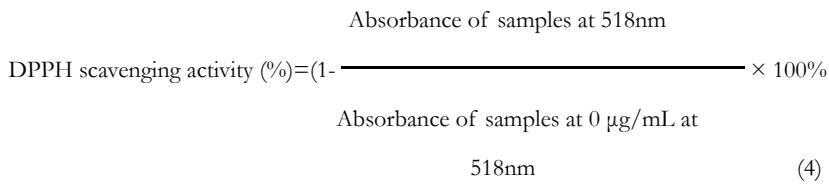

The $\mathrm{EC}_{50}$ was determined from the graph of DPPH scavenging activity (\%) against treatment concentration.

\section{Reducing power}

Reducing power of antioxidant that acts on the ET reaction ${ }^{37}$ was quantified according to Oyaizu ${ }^{38}$ with minor alterations. Ascorbic acid $(0-300 \mu \mathrm{g} / \mathrm{mL})$ served as the positive control. The ascorbic acid or extract (100 $\mu \mathrm{L})$ was mixed with phosphate buffer $(250 \mu \mathrm{L}, 0.2 \mathrm{M})$ and potassium ferricyanide $(250 \mu \mathrm{L}, 1 \%)$ and incubated at $50^{\circ} \mathrm{C}$ for $20 \mathrm{~min}$. Trichloroacetic acid $(250 \mu \mathrm{L}, 10 \%)$ was added and centrifuged at $250 \mathrm{x} \mathrm{g}$ for $10 \mathrm{~min}$. Supernatant $(250 \mu \mathrm{L})$ was mixed with iron (III) chloride $(250 \mu \mathrm{L}, 0.1 \%)$ and $\mathrm{ddH}_{2} \mathrm{O}(250 \mu \mathrm{L})$. The absorbance at $700 \mathrm{~nm}$ was measured using the microplate reader. The reducing power was expressed in $\mathrm{EC}_{50}$, calculated by adopting from the graph of absorbance against treatment concentration.

\section{Statistical analysis}

All experimental data $(n \geq 3)$ were presented as mean \pm standard error (SE). One-way analysis of variance (ANOVA) with Post Hoc test was performed using GraphPad Prism ver. 5.02 with a significant value of $P$ $\leq 0.05$.

\section{RESULTS}

\section{Cytotoxicity effect of S. platensis UMACC 159 extracts on PC-12Adh cells}

Cytotoxicity effect on PC-12Adh cells was determined using the reduction of MTT to formazan in viable cells. A natural product is considered as non-toxic when the $\mathrm{LD}_{50}$ or $\mathrm{IC}_{50}$ is more than $5 \mathrm{mg} / \mathrm{mL} .{ }^{39}$ Our findings on cell viability showed that all extracts are non-toxic and having $>50 \%$ cell viability for cell cultures dosed with more than $5 \mathrm{mg} / \mathrm{mL}$ (Table 1).

\section{The neuritogenic effect of S. platensis UMACC 159 extracts on PC-12Adh cells}

All solvent extracts demonstrated neuritogenic activity, with ethanol extract having the highest percentage of neurite-bearing cells (Figure 1). Methanol (12.11 $\pm 1.31 \%$ ) and ethanol $(17.13 \pm 2.31 \%)$ extracts showed maximum percentage at $6.25 \mu \mathrm{g} / \mathrm{mL}$, which are significantly $(P$ $\leq 0.001)$ higher than the negative control by 2.24 - and

Table 1: Effect of S. platensis UMACC 159 extracts on the viability of PC-12Adh cells.

\begin{tabular}{|c|c|}
\hline Extract & IC $_{50}(\mathbf{m g} / \mathbf{m L})$ \\
\hline Water & $7.18 \pm 0.58^{\mathrm{a}}$ \\
\hline Methanol & $9.63 \pm 0.71^{\mathrm{ab}}$ \\
\hline Ethanol & $10.37 \pm 0.78^{\mathrm{b}}$ \\
\hline
\end{tabular}

Data are expressed as mean $\pm \mathrm{SE}(n=3)$. Mean with different alphabet indicate significant difference $(P \leq 0.05)$ between each group by Tukey's test. A lower IC ${ }_{50}$ indicates higher cell viability inhibition.

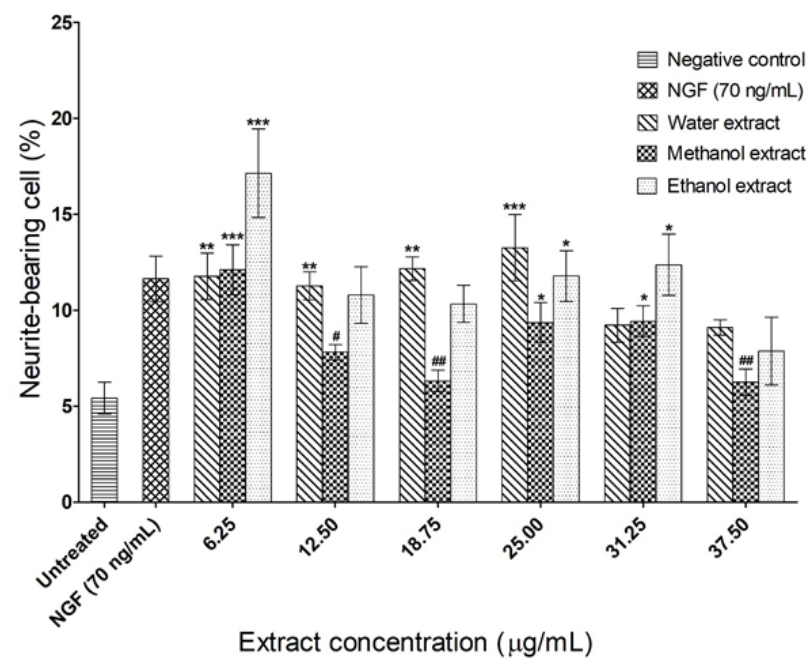

Figure 1: Percentage of neurite-bearing cells treated with different treatments. Data are expressed as mean \pm SE $(n=$ 3). * $P \leq 0.05$; ** $P \leq 0.01$; ${ }^{* *} P \leq 0.001$ when compared to the negative control; \# $P \leq \mathbf{0 . 0 5}$; \#\# $P \leq 0.01$ when compared to the nerve growth factor (NGF) by Dunnett's Multiple Comparison Test. 
3.16-fold respectively. As the concentration increased to $25 \mu \mathrm{g} / \mathrm{mL}$, water extract showed a maximum percentage of $13.26 \pm 1.73 \%$, which is significantly $(P \leq 0.001)$ higher than negative control by 2.45 -fold.

NGF (70 ng/mL, positive control) significantly ( $P \leq$ $0.05)$ increased the percentage of neurite-bearing cells by $11.63 \pm 1.18 \%$, which is 2.15 -fold higher than the negative control $(5.42 \pm 0.83 \%)$. All extracts at their respective optimal concentration had higher percentage than NGF, specifically 1.14- (water extract), 1.04(methanol extract), and 1.47-fold (ethanol extract) higher. At other concentrations, water (6.25 and 18.75 $\mu \mathrm{g} / \mathrm{mL}$ ) and ethanol extract (25 and $31.25 \mu \mathrm{g} / \mathrm{mL}$ ) also had slightly higher percentage (1.01- to 1.06 -fold) than NGF. Notably, only neurite-bearing cells in methanol extract showed significant $(P \leq 0.05)$ decreased $(0.54$ - to 0.67 -fold) at $12.5,18.755$, and $37.5 \mu \mathrm{g} / \mathrm{mL}$.

\section{Neuronal cytoskeleton analysis by immunofluorescence imaging}

Immunofluorescence imaging of neurofilament showed that neurite outgrowth was stimulated by the positive control (NGF) and all extracts of $S$. platensis. Enhanced neurite elongation of PC-12Adh cells was observed in the NGF and extracts treatments (Figure 2).

\section{Phytochemical contents of S. platensis UMACC 159 extracts}

Water, methanol, and ethanol with different solvent polarities were selected for extracting a wide range of
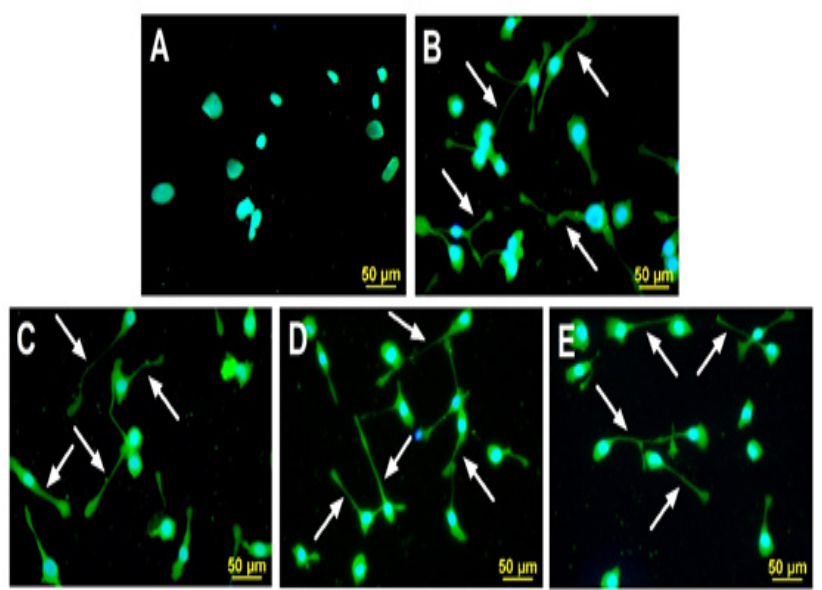

Figure 2: Morphology of PC-12Adh cells stained with antiNF-200 antibody. Cells were incubated with (A) negative control: F-12K culture medium, (B) positive control: $70 \mathrm{ng} /$ $\mathrm{mL}$ nerve growth factor (NGF), or $6.25 \mu \mathrm{g} / \mathrm{mL}$ of extract ((C) water, (D) methanol and (E) ethanol extracts) for $48 \mathrm{~h}$. Nuclei stained blue by DAPI; neurofilament stained green by anti-neurofilament-200 labelled with FITC. Arrows indicate neurite outgrowth. Photomicrographs were taken with 20x magnification; Scale bar: $50 \mu \mathrm{m}$. components from the samples. The extraction yield decreased with polarity of a solvent in the following order: water $(71.94 \pm 10.38 \%)>$ methanol $(17.14 \pm 2.20$ $\%)>$ ethanol $(13.78 \pm 0.70 \%)$ (Table 2$)$. Water extract has the highest yield, with approximately 4 - and 5-fold higher than methanol and ethanol extracts, respectively. The amount of phenolic and flavonoid contents extracted in the organic solvents were significantly $(P$ $\leq 0.05$ ) higher than the water extract (Table 2). TPC ranged from $32.69 \pm 1.73$ (water extract) to $49.09 \pm 1.35$ mg GAE/g (ethanol extract), while TFC ranged from $7.65 \pm 0.12$ (water extract) to $151.84 \pm 3.95 \mathrm{mg} \mathrm{QE} / \mathrm{g}$ (methanol extract). All the extracts contain carotenoids and terpenoids (Table 2).

\section{Antioxidant activities of S. platensis UMACC 159 extracts}

The lower $\mathrm{EC}_{50}$ value, the higher antioxidant activity of an extract. Overall, antioxidant activities of the organic solvent extracts were significantly $(P \leq 0.05)$ higher than the water extract (Table 3). Ethanol extract showed significant $(P \leq 0.05)$ higher ABTS $(1.34 \pm 0.01 \mathrm{mg} / \mathrm{mL})$ and DPPH $(0.45 \pm 0.04 \mathrm{mg} / \mathrm{mL})$ scavenging activities. However, methanol extract $(3.49 \pm 0.05 \mathrm{mg} / \mathrm{mL})$ had significant $(P \leq 0.05)$ higher reducing power than ethanol extract $(4.31 \pm 0.09 \mathrm{mg} / \mathrm{mL})$. Water extract gave the lowest antioxidant activities in scavenging ABTS (2.26 $\pm 0.04 \mathrm{mg} / \mathrm{mL})$ as well as DPPH $(1.91 \pm 0.01 \mathrm{mg} / \mathrm{mL})$, and the reducing power $(15.28 \pm 0.10 \mathrm{mg} / \mathrm{mL})$.

\section{DISCUSSION}

Natural products hold paramount potential since they were traditionally consumed as dietary supplements. Recently, marine algae and their constituents have been gaining more interest as nutraceuticals with neuroprotective activity. ${ }^{40}$ Antioxidative and antiinflammatoryactivities of S.platensisprotect dopaminergic neurons in the 6-OHDA-lesioned striatum of the PD rat model, ${ }^{25}$ possibly contributed by the polysaccharide. ${ }^{24} \mathrm{~S}$. platensis also alleviates morphological impairment after spinal cord injury and promotes recovery. ${ }^{26}$ However, there is no report regarding the neuritogenic effect of $S$. platensis. This study is the first to report the neuritogenic effect of S. platensis. All S. platensis UMACC 159 extracts promoted neuritogenesis in PC-12Adh cells, and the effect is comparable with the positive control (NGF). In addition, S. platensis UMACC 159 extracts possess phytochemicals such as phenolic, flavonoid, carotenoid, and terpenoid that exhibited promising antioxidant activity. 
Table 2: Extraction yield and the phytochemical contents of S. platensis UMACC 159 extracts.

\begin{tabular}{|c|c|c|c|c|c|}
\hline $\begin{array}{c}\text { Solvent } \\
\text { extract }\end{array}$ & $\begin{array}{c}\text { Yield } \\
(\%)\end{array}$ & $\begin{array}{c}\text { TPC } \\
(\mathbf{m g ~ G A E} / \mathbf{g})\end{array}$ & $\begin{array}{c}\text { TFC } \\
(\mathbf{m g ~ Q E / g )}\end{array}$ & Carotenoids & Terpenoids \\
\hline Water & $71.94 \pm 10.38$ & $32.69 \pm 1.73^{\mathrm{a}}$ & $7.65 \pm 0.12^{\mathrm{a}}$ & ++ & ++ \\
\hline Methanol & $17.14 \pm 2.20$ & $40.48 \pm 2.16^{\mathrm{b}}$ & $151.84 \pm 3.95^{\mathrm{b}}$ & ++ & ++ \\
\hline Ethanol & $13.78 \pm 0.70$ & $49.09 \pm 1.35^{\mathrm{c}}$ & $85.96 \pm 1.80^{\mathrm{c}}$ & ++ & ++ \\
\hline
\end{tabular}

Data are expressed as mean $\pm \mathrm{SE}(n=3)$. Mean with different alphabet indicate significant difference $(P \leq 0.05)$ between each group by Tukey's test. ++ indicates present. TPC - total phenolic content; TFC - total flavonoid content; mg GAE/g - mg of gallic acid equivalent (GAE) per $g$ of extract; $m g Q E / g$ - $m g$ of quercetin equivalent (QE) per $g$ of extract.

\begin{tabular}{|c|c|c|c|}
\hline \multirow{2}{*}{ Table 3: In vitro antioxidant activities of S. platensis UMACC 159 extracts. } \\
\hline \multirow{2}{*}{ Extract/control } & \multicolumn{3}{|c|}{ EC $_{50}(\mathrm{mg} / \mathrm{mL})$} \\
\cline { 2 - 4 } & ABTS & DPPH & Reducing power \\
\hline Extract & & & $15.28 \pm 0.10^{\mathrm{a}}$ \\
\hline Water & $2.26 \pm 0.04^{\mathrm{a}}$ & $1.91 \pm 0.01^{\mathrm{a}}$ & $3.49 \pm 0.05^{\mathrm{b}}$ \\
\hline Methanol & $1.65 \pm 0.01^{\mathrm{b}}$ & $0.86 \pm 0.06^{\mathrm{b}}$ & $4.31 \pm 0.09^{\mathrm{c}}$ \\
\hline Ethanol & $1.34 \pm 0.01^{\mathrm{c}}$ & $0.45 \pm 0.04^{\mathrm{c}}$ & \\
\hline Control & & & - \\
\hline Trolox & $0.008 \pm 0.0001^{\mathrm{d}}$ & - & $0.009 \pm 0.0003^{\mathrm{d}}$ \\
\hline Ascorbic acid & - & $0.001 \pm 0.0000^{\mathrm{d}}$ & \\
\hline
\end{tabular}

Data are expressed as mean $\pm \mathrm{SE}(n=3)$. Mean with different alphabet indicate significant difference $(P \leq 0.05)$ between each group by Tukey's test. Trolox serves as the positive control for ABTS; ascorbic acid serves as the positive control for DPPH and reducing power. A lower EC indicates a higher antioxidant activity. ABTS - 2,2'-Azino-bis(3ethylbenzothiazoline-6-sulfonic acid); DPPH - 2,2-Diphenyl-1-pircrylhydrazyl.

Exogenous neurotrophic factors help in the development of neuronal networks via neurite outgrowth. ${ }^{41}$ Our findings showed that the percentage of neurite-bearing cells of ethanol extract is 1.47- and 3.16-fold higher than the NGF and the negative control respectively, indicating its enhancing effect on the formation of complex neuronal network. S. platensis UMACC 159 ethanol and methanol extracts exhibit neuritogenic activity in PC-12Adh cells in a hormetic dose-response relationship, with the optimal concentration identified at $6.25 \mu \mathrm{g} / \mathrm{mL}$. C-phycocyanin, the bioactive compound in S. platensis water extract, has several therapeutic activities including antioxidative, anti-inflammatory, antibacterial and anticancer. ${ }^{42-44}$ However, our results suggest that the neuritogenic activity of $S$. platensis were attributed by unknown bioactive compound(s). To our best knowledge, very few studies have been conducted on the neuritogenic activity of microalgae. Besides our study, only the antillatoxin extracted from the cyanobacterium Lyngbya majuscula was reported to enhance neurite outgrowth by activating voltage-gated sodium channels. ${ }^{45}$ In accordance with our results, antillatoxin also promoted neurite outgrowth in a hormetic doseresponse. Jabba's group proposed that this relationship was primarily attributed to the regulation of intracellular calcium level, ${ }^{45}$ of which the optimal calcium level is essential for the neurite outgrowth. ${ }^{46,47}$ Antillatoxin significantly enhanced the neurite outgrowth by more than 2-fold at $30 \mathrm{nM}$, while our ethanol extract required a higher concentration of $6.25 \mu \mathrm{g} / \mathrm{mL}$. This is possibly due to the crude extract was used in comparison with the pure compound antillatoxin.

Bioactive compound(s) in S. platensis UMACC 159 ethanol extract remained unknown, but the neuritogenic effect may be attributed to the phenolic compound(s). Currently, two phenolic compounds, sargachromenol and sargaquinoic acid isolated from methanol extract of Sargassum macrocarpum have been reported to enhance NGF-dependent neuritogenesis in PC12 cells. ${ }^{48,49}$ Besides, pheophytin a, a chlorophyll-related compound isolated from methanol extract of Sargassum fulvellum had the same neuritogenic activity. ${ }^{50}$ It is noteworthy that the neuritogenic activity of these isolated bioactive compounds are NGF-dependent. In contrast, our ethanol extract is independent of NGF, suggesting a more prominent effect. Other than PC-12 cells, hippocampal neuron was also used to study the neuritogenic activity of Phaeophyta. Ethanol extract of S. fulvellum and Undaria pinnatifida were reported to enhance neuronal maturation and neuronal survival of hippocampal 
neurons. ${ }^{51,52}$ Neuritogenic activity of ethanol extract of Rhodophyta, such as Gracilariopsis chorda, Gelidium amansii, Kappaphycus alvarezii and Porphyra yezoensis, had also been reported in hippocampal neurons. ${ }^{53-56}$ In comparison, our ethanol extract has higher neuritogenic activity than all the Rhodophyta $(15 \mu \mathrm{g} / \mathrm{mL})$, except for $K$ alvarezii which had optimal activity at $1 \mu \mathrm{g} / \mathrm{mL}$.

Most microalgae are well-adapted to survive under a wide spectrum of environmental stresses. As a unicellular or simple multicellular microorganism, they can divide rapidly and react to the changes in an environment. Metabolic processes in algal cells allow the production of numerous metabolites, for example phenolic compounds, carotenoids, phycobiliproteins and alkaloids. ${ }^{57}$ Phenolic compounds are able to combat free radicals and suppress $\mathrm{AD}$ pathogenic cascade. ${ }^{58,59}$ For example, ethanol extracts of Chlorella sorokiniana and Chlorella minutissima with TPC of 14.21 and $13.35 \mathrm{mg}$ GAE/g respectively, exhibited radical scavenging activities and neuroprotective activities which include inhibition on cholinesterase activity and $A \beta_{1-42}$ aggregation. ${ }^{60}$ The amount of phenolic and flavonoid produced by $S$. platensis can be easily affected by environment factors, including the light irradiance intensity and culture medium. ${ }^{61,62}$ Kepekci's group ${ }^{62}$ reported that increase in light irradiance intensity significantly increase the amount of phenolic compound from 6.32 to $49.83 \mathrm{mg} \mathrm{GAE} / \mathrm{g}$. In comparison, all our extracts had considerably high phenolic content (32.69 \pm 1.73 to $49.09 \pm 1.35 \mathrm{mg} \mathrm{GAE} / \mathrm{g}$ ), indicating the potential of S. platensis UMACC 159 in the production of phenolic compounds.

Methanol and ethanol have been known as ideal solvents for polyphenol extraction, as these solvent systems aid in the denaturation of cell membranes, simultaneously dissolve and stabilize the polyphenols. ${ }^{63}$ Based on our results, the best TPC extracting solvent was ethanol as TPC decreased with increasing solvent polarity index. This could be caused by the presence of phenolic compounds that are more soluble in methanol and ethanol compared with water. ${ }^{63}$ In agreement with our findings, Shalaby and Shanab also reported that methanol extract of $S$. platensis has higher TPC than water extract. ${ }^{64}$ We also investigated the TFC as flavonoids are the most abundant polyphenols found in human diets. Our findings showed that the best TFC extracting solvent was methanol. In addition, in the present study, carotenoids and terpenoids are present in all the extracts. Carotenoids are a group of terpenoids with antioxidative properties that have displayed a diverse scope of therapeutic activities, including anti- inflammatory, immunomodulatory, neuroprotective, and anticarcinogen properties. ${ }^{65}$ Fucoxanthinol, a carotenoid isolated from Nitzschia laevis protects against neuroinflammatory response in BV-2 microglia. ${ }^{66}$ Terpenoids extracted from other $S$. platensis strains have also been reported for its neuroprotective activities against oxidative stress. ${ }^{67,68}$

According to our results, organic solvent extracts showed stronger antioxidant activities than water extract. In regard to ABTS and DPPH scavenging activities, the potency decreased as solvent polarity index increased, with ethanol extract having the highest activities. Shalaby and Shanab also reported that methanol extract of $S$. platensis had higher ABTS and DPPH scavenging activities than water extract. ${ }^{64}$ In fact, studies on red seaweed also reported a similar trend, ${ }^{69,70}$ but comparatively our ethanol extract $\left(\mathrm{EC}_{50}=0.45 \pm 0.04 \mathrm{mg} / \mathrm{mL}\right)$ had higher DPPH scavenging activity than the red seaweed Gracilaria changii $\left(\mathrm{EC}_{50}=2.36 \pm 0.13 \mathrm{mg} / \mathrm{mL}\right){ }^{69}$ Overall, our results suggest that the phenolic compounds in ethanol extract may be responsible for the DPPH and ABTS scavenging activities, while the flavonoid compounds in methanol extract may contribute to the reducing power. Phenolic compounds are one of the key metabolites that contribute to the DPPH scavenging activity in $S$. platensis ethanol extracts. ${ }^{71}$

\section{CONCLUSION}

In conclusion, we found that all $S$. platensis UMACC 159 extracts promote neuritogenesis in PC-12Adh cells, with ethanol extract possessing the highest neuritogenic activity. Our findings suggest the role of $S$. platensis UMACC 159 polyphenol as free radical scavengers, particularly flavonoid as ferric ions reducing agent. Bioactive compound(s) that regulates the neuritogenic activity remained unknown. However, our results demonstrated that the neuritogenic activity may be contributed by phenolic compound(s) present in $S$. platensis UMACC 159. These findings not only suggest the importance of the $S$. platensis in a healthy diet, but also trigger further research to provide insight on the molecular mechanisms involved the neuritogenic activity, which are beneficial in the production of functional food and drug for neurodegenerative disease.

\section{ACKNOWLEDGEMENT}

This investigation was supported by the Sunway University. Sincere appreciation is extended to the Mushroom Research Centre in University Malaya for the PC-12Adh cell line and the Institute of Ocean and Earth 
Sciences (IOES), University Malaya for the UMACC 159 Spirulina platensis culture for this study. Appreciation is also extended to the Ministry of Education Malaysia for the Higher Institution Centre of Excellence (HICoE) Phase II Fund (IOES-2014F) in the Institute of Ocean and Earth Sciences (IOES).

\section{CONFLICT OF INTEREST}

The authors declare that there are no conflicts of interest.

\section{ABBREVIATIONS}

\%: percentage; ${ }^{\circ} \mathrm{C}$ : Degree Celsius; $\mu \mathrm{g} / \mathrm{mL}$ : micrograms per millilitre; $\mu \mathrm{L}$ : microliter; 6-OHDA: 6-hydroxydopamine; ABTS: 2,2'-Azino-bis(3ethylbenzothiazoline-6-sulfonic acid); AD: Alzheimer's disease; ANOVA: analysis of variance; $\mathbf{A} \beta$ : amyloid beta; $\mathbf{C O}_{2}$; carbon dioxide; DAPI: 4'-6-diamidino2-phenylindole; $\mathbf{d d H}_{2} \mathbf{O}$ : double-distilled water; DMSO: dimethyl sulfoxide; DNA: deoxyribonucleic acid; DPPH: 2,2-Diphenyl-1-pircrylhydrazyl; $\mathbf{E C}_{50}$ : Half-maximum effective concentration; ET: electron transfer; FDA: Food and Drug Administration; FITC: Fluorescein isothiocyanate; g: gram; GAE: gallic acid equivalent; $\mathbf{h}$; hour; IC $_{50}$ : Half-maximal inhibition concentration; $\mathbf{L D}_{50}$ : median lethal dose; M: moles per liter; $\mathbf{m g}$ GAE/g: $\mathrm{mg}$ of GAE per $\mathrm{g}$ of extract; $\mathbf{m g}$ QE/g: $\mathrm{mg}$ of QE per g of extract; $\mathbf{m g}$ / mL: milligrams per millilitre; min: minute; $\mathrm{mL}$ : millilitre; mM: millimolar; MO; Missouri; MTT: 3-(4,5-dimethylthiazol-2-yl)-2,5-diphenyltetrazolium bromide; $\mathbf{n g} / \mathbf{m L}$ : nanograms per millilitre; NGF: nerve growth factor; NJ: New Jersey; nm: nanometer; nM: nanomolar; PD: Parkinson's disease; QE: quercetin equivalent; ROS: reactive oxygen species; SE: standard error; sp.: species; TFC: total flavonoid content; TPC: total phenolic content; UMACC: University of Malaya Algae Culture Collection; US: United States; UV: ultraviolet; v/v: volume by volume; ver.: version; w/v: weight by volume; WHO: World Health Organization; $\mathbf{x g}$ : times gravity.

\section{REFERENCES}

1. World Health Organization. The top 10 causes of death. 2020. [cited 2020 Sept 23]. Available from https://www.who.int/en/news-room/fact-sheets/detail/ the-top-10-causes-of-death.

2. Jankovic J. Motor fluctuations and dyskinesias in Parkinson's disease: Clinical manifestations. Mov Disord. 2005;20(S11):S11-6.

3. Müller T. Rivastigmine in the treatment of patients with Alzheimer's disease. Neuropsychiatr Dis Treat. 2007;3(2):211-8.

4. Numakawa T, Matsumoto T, Numakawa Y, Richards M, Yamawaki S, Kunugi $\mathrm{H}$. Protective action of neurotrophic factors and estrogen against oxidative stress-mediated neurodegeneration. J Toxicol. 2011.

5. Silva DJS, Dotti CG. Breaking the neuronal sphere: Regulation of the actin cytoskeleton in neuritogenesis. Nat Rev Neurosci. 2002;3(9):694-704.
6. Houlton J, Abumaria N, Hinkley SFR, Clarkson AN. Therapeutic potential of neurotrophins for repair after brain injury: A helping hand from biomaterials. Front Neurosci. 2019;13:790.

7. Olson L, Nordberg A, Holst VH, Bäckman L, Ebendal T, Alafuzoff I, et al. Nerve growth factor affects 11C-nicotine binding, blood flow, EEG, and verbal episodic memory in an Alzheimer patient (case report). J Neural Transm Park Dis Dement Sect. 1992;4(1):79-95.

8. Lauritano $\mathrm{C}$, Andersen $\mathrm{JH}$, Hansen E, Albrigtsen M, Escalera L, Esposito F, et al. Bioactivity screening of microalgae for antioxidant, anti-inflammatory, anticancer, anti-diabetes, and antibacterial activities. Front Mar Sci. 2016;3:68.

9. Choi JY, Hwang CJ, Lee HP, Kim HS, Han SB, Hong JT. Inhibitory effect of ethanol extract of Nannochloropsis oceanica on lipopolysaccharideinduced neuroinflammation, oxidative stress, amyloidogensis and memory impairment. Oncotarget. 2017;8(28):45517-30.

10. Kim KN, Cha SH, Kim EA, Kang MC, Yang HM, Kim MJ, et al. Neuroprotective effects of Nannochloropsis oceanica against AAPH-induced oxidative DNA damage in HT22 cells. Int J Pharmacol. 2012;8(6):527-34.

11. Lai YJ. Omega-3 fatty acid obtained from Nannochloropsis oceanica cultures grown under low urea protect against Abeta-induced neural damage. J Food Sci Technol. 2015;52(5):2982-9.

12. Gumbo JR, Nesamvuni CN. A Review: Spirulina a source of bioactive compounds and nutrition. J Chem Pharm Sci. 2017;10(3):1317-25.

13. Fox RD. Spirulina: Production and Potential. New York: Edisud; 1996.

14. Balachandran P, Pugh ND, Ma G, Pasco DS. Toll-like receptor 2-dependent activation of monocytes by Spirulina polysaccharide and its immune enhancing action in mice. Int Immunopharmacol. 2006;6(12):1808-14.

15. Syarina PNA, Karthivashan G, Abas F, Arulselvan P, Fakurazi S. Wound healing potential of Spirulina platensis extracts on human dermal fibroblast cells. EXCLI J. 2015;14:385-93.

16. Fujitani N, Sakaki S, Yamaguchi Y, Takenaka H. Inhibitory effects of microalgae on the activation of hyaluronidase. J Appl Phycol. 2001;13(6):489-92.

17. Akbarizare $\mathrm{M}$, Ofoghi $\mathrm{H}$, Hadizadeh $\mathrm{M}$, Moazami N. In vitro assessment of the cytotoxic effects of secondary metabolites from Spirulina platensis on hepatocellular carcinoma. Egypt Liver J. 2020;10(1):11.

18. Ramadan MF, Asker MMS, Ibrahim ZK. Functional bioactive compounds and biological activities of Spirulina platensis lipids. Czech J Food Sci. 2008;26(3):211-22.

19. Kok YY, Chu WL, Phang SM, Mohamed SM, Naidu R, Lai PJ, et al. Inhibitory activities of microalgal extracts against Epstein-Barr virus DNA release from lymphoblastoid cells. J Zhejiang Univ Sci B. 2011;12(5):335-45.

20. Mallikarjun GKG, Udaya SK, Sarada R, Ravishankar GA. Supercritical $\mathrm{CO}_{2}$ extraction of functional compounds from Spirulina and their biological activity. J Food Sci Technol. 2015;52(6):3627-33.

21. Liu JG, Hou CW, Lee SY, Chuang Y, Lin CC. Antioxidant effects and UVB protective activity of Spirulina (Arthrospira platensis) products fermented with lactic acid bacteria. Process Biochem. 2011;46(7):1405-10.

22. Nasirian F, Dadkhah M, Moradi-Kor N, Obeidavi Z. Effects of Spirulina platensis microalgae on antioxidant and anti-inflammatory factors in diabetic rats. Diabetes, Metab Syndr Obes Targets Ther. 2018;11:375-80.

23. Gargouri M, Hamed H, Akrouti A, Dauvergne X, Magné C, Feki EA. Effects of Spirulina platensis on lipid peroxidation, antioxidant defenses, and tissue damage in kidney of alloxan-induced diabetic rats. Appl Physiol Nutr Metab. 2018;43(4):345-54.

24. Zhang F, Lu J, Zhang JG, Xie JX. Protective effects of a polysaccharide from Spirulina platensis on dopaminergic neurons in an MPTP-induced Parkinson's disease model in C57BL/6J mice. Neural Regen Res. 2015;10(2):308-13.

25. Lima FAV, Joventino IP, Joventino FP, Almeida DAC, Neves KRT, Carmo DMR, et al. Neuroprotective activities of Spirulina platensis in the 6-OHDA model of Parkinson's disease are related to its anti-inflammatory effects. Neurochem Res. 2017;42(12):3390-400.

26. Aziz I, Ramli MDC, Zain NSM, Sanusi J. Behavioral and histopathological study of changes in spinal cord injured rats supplemented with Spirulina platensis. Evidence-based Complement Altern Med. 2014;2014:871657.

27. Greene LA. The importance of both early and delayed responses in the biological actions of nerve growth factor. Trends Neurosci. 1984;7(3):91-4. 
28. Pang JR, Goh VMJ, Tan CY, Phang SM, Wong KH, Yow YY. Neuritogenic and in vitro antioxidant activities of Malaysian Gracilaria manilaensis Yamamoto and Trono. Journal of Applied Phycology. 2018;30(6):3253-60.

29. Singleton VL, Orthofer R, Lamuela-Raventós RM. Analysis of total phenols and other oxidation substrates and antioxidants by means of folin-ciocalteu reagent. Methods Enzymol. 1999;299:152-78.

30. Pękal A, Pyrzynska K. Evaluation of aluminium complexation reaction for flavonoid content assay. Food Anal Methods. 2014;7(9):1776-82.

31. Sharma P, Gomathi D, Ravikumar G, Kalaiselvi M, Chandrasekaran U. Phytochemical screening and high performance thin layer chromatography finger printing analysis of green hull of Juglans regia (walnut). El Mednifico J. 2014;2(3):235.

32. Batista-Gonzalez A, Silva ADO, Vidal-Novoa A, Pinto J, Mancini D, Mancini-Filho J. Analysis of in vitro and in vivo antioxidant properties of hydrophilic fractions from the seaweed Halimeda monile L. J Food Biochem. 2012;36(2):189-97.

33. Huang D, Ou B, Prior RL. The chemistry behind antioxidant capacity assays. J Agric Food Chem. 2005;53(6):1841-56.

34. Miller NJ, Rice-Evans C, Davies MJ, Gopinathan V, Milner A. A novel method for measuring antioxidant capacity and its application to monitoring the antioxidant status in premature neonates. Clin Sci. 1993;84(4):407-12.

35. Re R, Pellegrini N, Proteggente A, Pannala A, Yang M, Rice-Evans C. Antioxidant activity applying an improved ABTS radical cation decolorization assay. Free Radic Biol Med. 1999;26(9-10):1231-7.

36. Brand-Williams W, Cuvelier ME, Berset C. Use of a free radical method to evaluate antioxidant activity. LWT - Food Sci Technol. 1995;28(1):25-30.

37. Anandjiwala S, Bagul M, Parabia M, Rajani M. Evaluation of free radical scavenging activity of an ayurvedic formulation, Panchvalkala. Indian J Pharm Sci. 2008;70(1):31-5.

38. Oyaizu M. Studies on products of browning reaction. Antioxidative activities of products of browning reaction prepared from glucosamine. Japanese J Nutr Diet. 1986;44(6):307-15.

39. United Nation. Globally harmonized system of classification and labelling of chemicals (GHS). Fourth. New York and Geneva: United Nations; 2011;1561.

40. Brinton RD, Yamazaki RS. Advances and challenges in the prevention and treatment of Alzheimer's disease. Pharm Res. 1998;15(3):386-98.

41. McAllister AK. Cellular and molecular mechanisms of dendrite growth. Cereb Cortex. 2000;10(10):963-73.

42. Mitra S, Siddiqui WA, Khandelwal S. C-Phycocyanin protects against acute tributyltin chloride neurotoxicity by modulating glial cell activity along with its anti-oxidant and anti-inflammatory property: A comparative efficacy evaluation with N-acetyl cysteine in adult rat brain. Chem Biol Interact. 2015;238:138-50.

43. Rathnasamy SK, Rajendran DS, Balaraman HB, Viswanathan G. Functional deep eutectic solvent-based chaotic extraction of phycobiliprotein using microwave-assisted liquid-liquid micro-extraction from Spirulina (Arthrospira platensis) and its biological activity determination. Algal Res. 2019;44:101709.

44. Gupta NK, Gupta KP. Effects of C-Phycocyanin on the representative genes of tumor development in mouse skin exposed to 12-O-tetradecanoyl-phorbol13-acetate. Environ Toxicol Pharmacol. 2012;34(3):941-8.

45. Jabba S V, Prakash A, Dravid SM, Gerwick WH, Murray TF. Antillatoxin, a novel lipopeptide, enhances neurite outgrowth in immature cerebrocortical neurons through activation of voltage-gated sodium channels. J Pharmacol Exp Ther. 2010;332(3):698-709.

46. Gomez TM, Spitzer NC. Regulation of growth cone behavior by calcium: New dynamics to earlier perspectives. J Neurobiol. 2000;44(2):174-83.

47. Hui K, Fei GH, Saab BJ, Su J, Roder JC, Feng ZP. Neuronal calcium sensor-1 modulation of optimal calcium level for neurite outgrowth. Development. 2007;134(24):4479-89.

48. Tsang CK, Ina A, Goto T, Kamei Y. Sargachromenol, a novel nerve growth factor-potentiating substance isolated from Sargassum macrocarpum, promotes neurite outgrowth and survival via distinct signaling pathways in PC12D cells. Neuroscience. 2005;132(3):633-43.

49. Kamei Y, Tsang CK. Sargaquinoic acid promotes neurite outgrowth via protein kinase A and MAP kinases-mediated signaling pathways in PC12D cells. Int J Dev Neurosci. 2003;21(5):255-62.
50. Ina A, Hayashi KI, Nozaki H, Kamei Y. Pheophytin a, a low molecular weight compound found in the marine brown alga Sargassum fulvellum, promotes the differentiation of PC12 cells. Int J Dev Neurosci. 2007;25(1):63-8.

51. Hannan MA, Kang JY, Hong YK, Lee HS, Chowdhury MTH, Choi JS, et al. A brown alga Sargassum fulvellum facilitates neuronal maturation and synaptogenesis. Vitr Cell Dev Biol - Anim. 2012;48(8):535-44.

52. Hannan MA, Mohibbullah M, Hwang SY, Lee K, Kim YC, Hong YK, et al. Differential neuritogenic activities of two edible brown macroalgae, Undaria pinnatifida and Saccharina japonica. Am J Chin Med. 2014;42(6):1371-84.

53. Mohibbullah M, Hannan MA, Park IS, Moon IS, Hong YK. The edible red seaweed Gracilariopsis chorda promotes axodendritic architectural complexity in hippocampal neurons. J Med Food. 2016;19(7):638-44.

54. Hannan MA, Kang JY, Hong YK, Lee H, Choi JS, Choi IS, et al. The marine alga Gelidium amansii promotes the development and complexity of neuronal cytoarchitecture. Phyther Res. 2013;27(1):21-9.

55. Tirtawijaya G, Mohibbullah M, Meinita MDN, Moon IS, Hong YK. The ethanol extract of the rhodophyte Kappaphycus alvarezii promotes neurite outgrowth in hippocampal neurons. J Appl Phycol. 2016;28(4):2515-22.

56. Mohibbullah M, Bhuiyan MMH, Hannan MA, Getachew P, Hong YK, Choi JS, et al. The edible red alga Porphyra yezoensis promotes neuronal survival and cytoarchitecture in primary hippocampal neurons. Cell Mol Neurobiol. 2016;36(5):669-82.

57. Olasehinde T, Olaniran A, Okoh A. Therapeutic potentials of microalgae in the treatment of Alzheimer's disease. Molecules. 2017;22(3):480.

58. Machu L, Misurcova L, Ambrozova VJ, Orsavova J, Mlcek J, Sochor J, et al. Phenolic content and antioxidant capacity in algal food products. 2015;20(1):1118-33.

59. Cole GM, Lim GP, Yang F, Teter B, Begum A, Ma Q, et al. Prevention of Alzheimer's disease: Omega-3 fatty acid and phenolic anti-oxidant interventions. Neurobiol Aging. 2005;26(Suppl 1):133-6.

60. Olasehinde TA, Odjadjare EC, Mabinya LV, Olaniran AO, Okoh Al. Chlorella sorokiniana and Chlorella minutissima exhibit antioxidant potentials, inhibit cholinesterases and modulate disaggregation of $\beta$-amyloid fibrils. Electron $\mathrm{J}$ Biotechnol. 2019;40:1-9.

61. Gabal AAA, Khaled AEM, El-Sayed HS, Aboul-Ela HM, Shalaby OK, Khaled AA, et al. Optimization of Spirulina platensis biomass and evaluation of its protective effect against chromosomal aberrations of bone marrow cells. Fish Aquac J. 2018;10(260):2.

62. Kepekçi RA, Polat S, Çelik A, Bayat N, Saygideger SD. Protective effect of Spirulina platensis enriched in phenolic compounds against hepatotoxicity induced by $\mathrm{CCl}_{4}$. Food Chem. 2013;141(3):1972-9.

63. Dai J, Mumper RJ. Plant phenolics: Extraction, analysis and their antioxidant and anticancer properties. Molecules. 2010;15(10):7313-52.

64. Shalaby EA, Shanab SMM. Comparison of DPPH and ABTS assays for determining antioxidant potential of water and methanol extracts of Spirulina platensis. Indian J Geo-Marine Sci. 2013;42(5):556-64.

65. Higuera-Ciapara I, Félix-Valenzuela L, Goycoolea FM. Astaxanthin: A review of its chemistry and applications. Crit Rev Food Sci Nutr. 2006;46(2):185-96.

66. Li Y, Liu L, Sun P, Zhang $\mathrm{Y}, \mathrm{Wu} \mathrm{T}$, Sun $\mathrm{H}$, et al. Fucoxanthinol from the diatom Nitzschia laevis ameliorates neuroinflammatory responses in lipopolysaccharide-stimulated BV-2 microglia. Mar Drugs. 2020;18(2):116.

67. Morais DMG, Vaz BDS, Morais EGD, Costa JAV. Biologically active metabolites synthesized by microalgae. Biomed Res Int. 2015;2015:835761.

68. Kanhere R, Anjana A, Anbu J, Sumithra M, Ahamed N. Neuroprotective and antioxidant potential of terpenoid fraction from Hygrophila auriculata against transient global cerebral ischemia in rats. Pharm Biol. 2013;51(2):181-9.

69. Chan PT, Matanjun P, Yasir SM, Tan TS. Antioxidant activities and polyphenolics of various solvent extracts of red seaweed, Gracilaria changii. J Appl Phycol. 2015;27(6):2377-86.

70. Zakaria NA, Ibrahim D, Sulaiman SF, Supardy NA. Assessment of antioxidant activity, total phenolic content and in-vitro toxicity of Malaysian red seaweed, Acanthophora spicifera. J Chem Pharm Res. 2011;3(3):182-91.

71. Jaime L, Mendiola JA, Herrero M, Soler-Rivas C, Santoyo S, Señorans FJ, et al. Separation and characterization of antioxidants from Spirulina platensis microalga combining pressurized liquid extraction, TLC, and HPLC-DAD. J Sep Sci. 2005;28(16):2111-9. 
PICTORIAL ABSTRACT

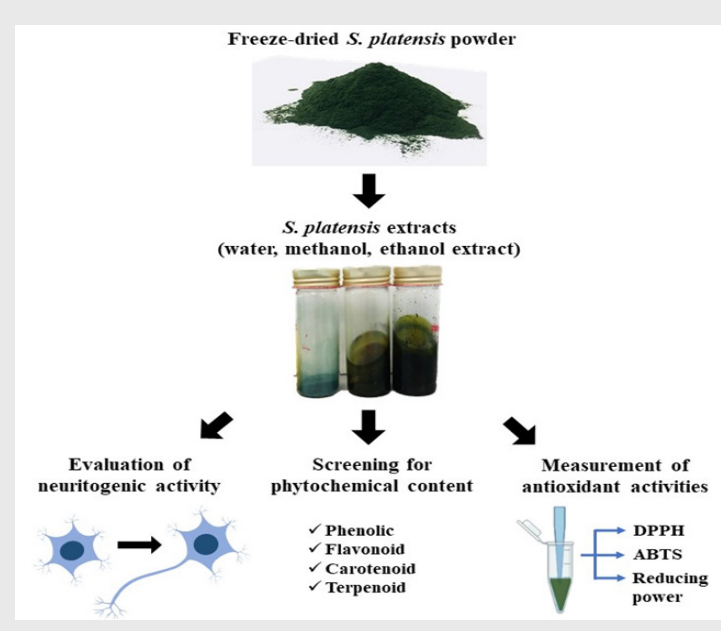

\section{SUMMARY}

The blue-green microalga, Spirulina platensis is wellknown for the high content of diverse nutrients and has been reported with several therapeutic properties. Current study demonstrated that all $S$. platensis UMACC 159 extracts exhibit neuroprotective activity by promoting neuritogenesis in PC-12Adh cells, with ethanol extract possessing the highest neuritogenic activity. In addition, our findings suggest the role of phenolic compound(s) in the antioxidant and neuritogenic activities of $S$. platensis UMACC 159 ethanol extract. These findings further emphasise the importance of $S$. platensis as a food supplement. Nevertheless, further research on the molecular mechanisms involved in neuritogenic activity would be beneficial in the production of functional food and drug for neurodegenerative disease.

\begin{abstract}
About Authors

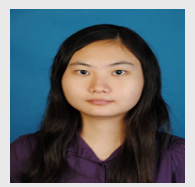

Ms. Ee-Ling Ngu is a postgraduate student at the Department of Biological Sciences, School of Medical and Life Sciences, Sunway University. Her research interest is to explore the potential of natural product, particularly marine algae in the development of functional food or treatment for neurological disease. Her research has been focussing on the neuroprotective effect of blue-green microalga, Spirulina platensis using cellular models.

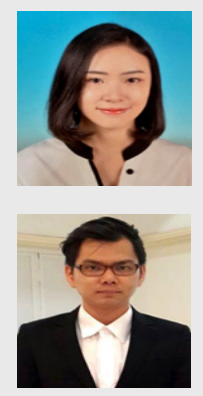

Ms. Chen-Lin Ko is a student graduated from Sunway University in 15 September 2017. She is graduated with Bachelor of Science in Medical Biotechnology. Her Final Year Project on Preliminary study of phytochemical and in vitro antioxidant activities of superfood Spirulina platensis. She is currently a senior product specialist at local pharmaceutical company to promote and share company's products to the Healthcare Professional.

Mr. Cheng-Yau Tan is currently pursuing his doctoral degree at the Sunway University on the exploration of algae biofertilizing potential. He has been working on the research for application of algae including mass cultivation technologies, wastewater/ $\mathrm{CO}_{2}$ bioremediation, biofuel, biocement and nutraceutical. He is also engaged with the Algae Research Laboratory (University of Malaya) and the University of Malaya Centre of Innovation and Commercialization in providing consultancy and service to facilitate the technology transfer and commercialization of some algae research outputs.

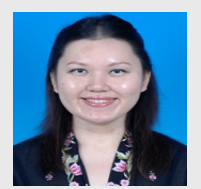

Dr. Kah-Hui Wong is a Senior Lecturer at the Department of Anatomy, Faculty of Medicine, University of Malaya. Her research focuses on using alternative medicines, in particular the culinary and medicinal mushrooms for neuroprotection and neuroregeneration in cellular and animal models. She is engaged with Neurology Unit of UMMC, Ganofarm R\&D Sdn Bhd and Corielle Institute for Medical Research (New Jersey, USA) to pursuit scientific research leading to treatments for hereditary ataxia.

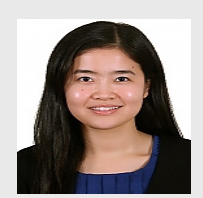

Dr. Yoon-Yen Yow is a Senior Lecturer at the School of Medical and Life Sciences, Sunway University. She is an algae biotechnologist and her research focuses on developing of high-value products from algae. She is exploring the pharmacological effects of algae in areas including neuroprotection, cosmeceuticals and their anti-microbial effects against infectious diseases. She is also interested in the study of molecular phylogeny and genetic diversity of algae, and invasive Pomacea apple snails in Malaysia. In line with Sunway University's commitment to the United Nations Sustainable Development Goals (UNSDGs), she looks forward to discovering how algae play a role in the SDGs with the aim to promote well-being for all.
\end{abstract}




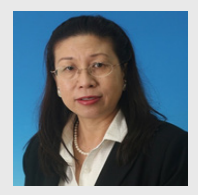

Emeritus Professor Dr. Siew-Moi Phang is the pioneered Applied Phycological Research in Malaysia. Her research group focuses on the areas including Taxonomy, Biotechnology, Bioremediation and Algal Renewable Energy. She has produced 210 ISI and 40 Scopus journal publications, 17 books and 57 book chapters; with 6 patents granted, 11 filed; 4 copyright filed; produced 32 PhDs and 68 Masters graduates. She is presently working as an Emeritus Professor, University of Malaya and was recently appointed the Deputy Vice Chancellor (Research \& Postgraduate), UCSI University, Malaysia.

Cite this article: Ngu EL, Ko CL, Tan CY, Wong KH, Phang SM, Yow YY. Phytochemical Profiling and in vitro Screening for Neuritogenic and Antioxidant Activities of Spirulina platensis. Indian J of Pharmaceutical Education and Research. 2021;55(3):812-22. 